\title{
PENGARUH PEMBERIAN INSENTIF TERHADAP DISIPLIN KERJA PADA ANGGOTA SATUAN POLISI PAMONG PRAJA DI KABUPATEN PESAWARAN
}

\author{
Andi F Tilaar \\ STIE Gentiaras \\ Andif.tilaar@gmail.com
}

\begin{abstract}
Abstrak Objek Penelitian adalah Satuan Polisi Pamong Praja Kabupaten Pesawaran yang merupakan salah satu Satuan Kerja Perangkat Daerah yang memberikan pelayanan berupa jasa untuk menegakkan peraturan daerah (perda) dan peraturan kepala daerah (perkada), menyelenggarakan ketertiban umum dan ketentraman masyarakat serta menyelenggarakan perlindungan masyarakat (linmas). Perumusan masalah dalam penelitian adalah : "Apakah pemberian insentif berpengaruh terhadap disiplin kerja anggota satuan polisi pamong praja di kabupaten pesawaran ?".sedangkan tujuan peneliitian untuk mengetahui pengaruh pemberian insentif terhadap disiplin kerja anggota Satuan Polisi Pamong Praja Kabupaten Pesawaran. Metode yang digunakan adalah analisis kualitatif dan analisis kuantitatif, dalam penelitian ini populasi berjumlah 400 orang.Dengan sampel 40 responden. Analisis data kuantitatif dengan rumus analisis regresi linear sederhana, yakni Koefisien diterminasi $=\mathrm{R}^{2} \mathrm{x} 100 \%-0,673^{2} \times 100 \%=0,453 \times 100 \%=45,3 \%$. variabel insentif menjelaskan variasi perubahan terhadap variabel disiplin kerja pada Anggota Satuan Polisi Pamong Praja di Kabupaten Pesawaran sebesar 45,3 \%. Kesimpulan bahwa hipotesis yang diajukan adalah; "Pemberian insentif berpengaruh terhadap disiplin kerja anggota Satuan Polisi Pamong Praja di Kabupaten Pesawaran", diterima. Dengan saran bahwa hendaknya memiliki kesadaran untuk selalu dan harus memperhatikan aspek disiplin, terutama aspek kesadaran dan kesediaan mentaati semua peraturan organisasi dan norma-norma sosial yang berlaku. Salah satunya yaitu selalu datang dan pulang tepat pada waktunya dan mengerjakan semua pekerjaannya dengan baik.
\end{abstract}

Kata kunci: insentif dan disiplin kerja.

\section{PENDAHULUAN}

Otonomi daerah bukanlah merupakan suatu kebijakan yang baru dalam penyelenggaraan pemerintahan di Indonesia. Konsep desentralisasi dan otonomi daerah dilihat dari persfektif organisasi dan manajemen lebih menekankan pada aspek efisiensi dan efektivitas pelaksanaan tugas. Setiap perusahaan baik itu perusahaan jasa maupun perusahaan pemerintah ataupun swasta dalam menjalankan usahanya pasti memiliki tujuan.

Hal ini tentu saja didorong oleh tingkat disiplin kerja dari masing-masing pegawai dalam menyelesaikan pekerjaan yang di tetapkan. Peningkatan hasil kerja yang efektif pada suatu organisasi maupun perusahaan akan sangat dipengaruhi oleh program kerja yang ditetapkan oleh organisasi maupun perusahaan tersebut. Dengan adanya insentif yang diberikan oleh perusahaan kepada setiap pegawainya, maka setiap pegawai akan lebih bersemangat dalam mencapai tujuan yang telah di tetapkan agar lebih efektif dan efisien.

Menurut Justin T Sirait (2006 : 200), insentif merupakan sesuatu yang mendorong atau mempunyai kecendrungan merangsang suatu kegiatan. Insentif adalah motif-motif dan imbalan-imbalan yang dibentuk untuk memperbaiki produksi. Sedangkan menurut Heidjrachman dan Suad Husnan (2007 : 148). 
Dalam rangka penyelengaraan pelayanan prima tentunya harus didukung oleh sumber daya manusia yang ada di Satuan Polisi Pamong Praja Kabupaten Pesawaran tersebut untuk mencapai visi dan misi yang telah ditetapkan. Pemberian insentif melalui pemerintah diharapkan dapat berdampak positif terhadap kinerja Anggota Satuan Polisi Pamong Praja Kabupaten Pesawaran selaku sumber daya manusia yang secara langsung atau tidak langsung sengaja diatur (manage) untuk meningkatkan disiplin kerja Anggota Satuan Polisi Pamong Praja Kabupaten Pesawaran.

Pemberian insentif ini merupakan suatu cara untuk meningkatkan disiplin kerja Anggota Satuan Polisi Pamong Praja Kabupaten Pesawaran. Sehingga diharapkan, kinerja Anggota Satuan Polisi Pamong Praja Kabupaten Pesawaran juga dapat meningkat. Berikut ini besarnya insentif yang diberikan kepada Anggota Satuan Polisi Pamong Praja berdasarkan unit kerjanya yaitu :

\section{Daftar Besaran Insentif yang Diterima Anggota Satuan Polisi Pamong Praja Kabupaten Pesawaran Tahun 2018}

\begin{tabular}{|c|c|c|}
\hline $\begin{array}{l}\mathrm{N} \\
\mathrm{O}\end{array}$ & UNIT & INSENTIF \\
\hline 1 & STAF & Rp 200.000,- \\
\hline 2 & PROVOS (PTI) & Rp 200.000,- \\
\hline 3 & PIKET & Rp 200.000,- \\
\hline 4 & PAMWAL & Rp 200.000,- \\
\hline 5 & KORSIK & Rp 200.000,- \\
\hline 6 & TRANTIB & Rp 200.000,- \\
\hline 7 & DALMAS A & Rp 200.000,- \\
\hline 8 & DALMAS B & Rp 200.000,- \\
\hline 9 & DALMAS C & Rp 200.000,- \\
\hline $\begin{array}{l}1 \\
0\end{array}$ & OPERATOR & Rp 200.000,- \\
\hline 1 & PENGAWALA & Rp 200.000,- \\
\hline 1 & $\mathrm{~N}$ & \\
\hline 1 & PENGAWALA & Rp 200.000,- \\
\hline 2 & N TERTUTUP & \\
\hline 1 & PENGAWAS & Rp 250.000,- \\
\hline 3 & PIKET & \\
\hline 1 & PEMADAM & Rp 300.000,- \\
\hline 4 & KEBAKARAN & \\
\hline $\begin{array}{l}1 \\
5\end{array}$ & INTELKAM & Rp 250.000,- \\
\hline
\end{tabular}

Sumber : Data didapat tahun 2019
Pemberian insentif yang dilakukan oleh Satuan Polisi Pamong Praja Kabupaten Pesawaran didasarkan pada Kebijakan dari Kepala Daerah agar dalam pemberian insentif ini akan memberikan dorongan yang kuat untuk meningkatkan kesadaran tenaga kerja untuk terus bekerja lebih giat.

Hal tersebut juga akan menyebabkan tenaga kerja untuk lebih bertanggung jawab dalam menyelesaikan tugas yang dibebankan kepadanya sesuai dengan prosedur dan bertanggung jawab atas hasil kerja, ketepatan penyelesaian kerja dan pemanfaatan jam kerja yang ada. Karena setiap tenaga kerja haruslah mengikuti aturan kerja yang ada dan taat terhadap setiap kebijakan yang bertujuan untuk mencapai tujuan yang telah dibuat oleh lembaga atau perusahaan. Dengan terciptanya nilai-nilai kepatuhan, maka seorang pegawai akan secara sadar mengikuti aturan yang telah ditetapkan pimpinannya.

Akan tetapi, mulai bulan januari tahun 2019 ini pemberian insentif sudah diberhentikan. Ini mengakibatkan menurunnya tingkat disiplin kerja Anggota Satuan Polisi Pamong Praja Kabupaten Pesawaran. Hal ini dilihat dari tingkat kehadiran mereka yang mulai menurun.

Kurangnya motivasi kerja juga merupakan salah satu faktor yang menjadi alasan menurunnya tingkat disiplin kerja Anggota akibat mengikuti temannya yang kurang disiplin tapi tidak mendapat tindakan tegas dari pimpinan. Dari kejadian tersebut, dapat dilihat bahwa kurangnya pengawasan dari pimpinan terhadap pelanggaran yang terjadi.

Disisi lain, disiplin diri akan memperlancar kegiatan yang bersifat kelompok., apalagi kalau tugas kelompok itu berkaitan dengan ketepatan waktu, dimana jika tidak terselesaikan dalam waktu yang ditentukan dampaknya akan menghambat proses kerja bidang lainnya. Salah satu bentuk motivasi dari pimpinan 
adalah pemberian hukuman yang diberikan terhadap pelanggaran-pelanggaran aturan yang telah dilakukan dan pemberian insentif sebagai bentuk penghargaan terhadap tingginya loyalitas kerja yang telah dilakukannya.

Persentasi Tingkat Kehadiran Anggota Satuan Polisi Pamong Praja Kabupaten Pesawaran mulai bulan januari 2018 s.d. februari 2019

\begin{tabular}{|l|c|c|}
\hline \multicolumn{1}{|c|}{ Bulan } & $\begin{array}{c}\text { Persentase Tingkat Kehadiran } \\
\text { Saat Ini (\%) }\end{array}$ & $\begin{array}{c}\text { Persentase } \\
\text { Tingkat } \\
\text { Kehadiran yang } \\
\text { Diharapkan (\%) }\end{array}$ \\
\hline Januari 2018 & $87,8 \%$ & $90 \%$ \\
Februari 2018 & $84,5 \%$ & $90 \%$ \\
Maret 2018 & $88 \%$ & $90 \%$ \\
April 2018 & $87,13 \%$ & $90 \%$ \\
Mei 2018 & $80,7 \%$ & $90 \%$ \\
Juni 2018 & $86,1 \%$ & $90 \%$ \\
Juli 2018 & $88 \%$ & $90 \%$ \\
Agustus 2018 & $87,8 \%$ & $90 \%$ \\
September & $80,9 \%$ & $90 \%$ \\
2018 & $88,74 \%$ & $90 \%$ \\
Oktober 2018 & $86,5 \%$ & $90 \%$ \\
November 2018 & $87,12 \%$ & $90 \%$ \\
Desember 2018 & $79 \%$ & $90 \%$ \\
Januari 2019 & $77,6 \%$ & $90 \%$ \\
Februari 2019 & \multicolumn{2}{|c|}{ Sumber : Bagian Ketentraman dan Ketertiban Umum Satuan } \\
Sumban \\
Polisi Pamong Praja Kabupaten Pesawaran
\end{tabular}

Berdasarkan uraian diatas maka penulis tertarik melakukan penelitian tentang disiplin kerja anggota yang salah satunya dipengaruhi oleh pemberian insentif. Berdasarkan penjelasan tersebut, maka penulis tertarik melakukan penelitian yang berjudul "Pengaruh Pemberian Insentif Terhadap Disiplin Kerja Anggota Satuan Polisi di Kabupaten Pesawaran"

\section{KAJIAN TEORI}

\section{Kompetensi Sumber Daya Manusia}

Manajemen Sumber Daya Manusia adalah suatu bidang manajemen yang khusus mempelajari hubungan dan peranan manusia dalam suatu organisasi. Unsur Manajemen Sumber Daya Manusia adalah manusia yang merupakan tenaga kerja pada organisasi baik swasta maupun pemerintahan. Dengan demikian, fokus yang dipelajari MSDM hanyalah masalah yang berhubungan dengan tenaga kerja manusia saja.

Menurut Malayu S. P Hasibuan (2010:12) "Pengertian Manajemen Sumber Daya Manusia adalah ilmu dan seni mengatur hubungan dan peranan tenaga kerja agar efektif dan efisien membantu terwujudnya tujuan organisasi, karyawan dan masyarakat."

Dari pengertian di atas dapat disimpulkan bahwa Manajemen Sumber Daya Manusia mengatur tenaga kerja manusia sedemikian rupa sehingga terwujudnya tujuan organisasi, kepuasan karyawan dan masyarakat. Menurut Heidjrachman dan Suad Husnan (2007:15), pengertian manajemen sumber daya manusia adalah perencanaan, pengorganisasian, pengarahan dan pengawasan dari pengadaan dan pengembangan, pemberian kompensasi, pengintegrasian dan pemeliharaan tenaga kerja dengan maksud untuk membantu mencapai tujuan perusahaan, individu dan masyarakat.

Manusia sebenarnya adalah manajemen yang mengkhususkan dalam bidang personalia atau bidang kepegawaian, Manajemen personalia menyangkut masalah pemanfaatan sumber daya manusia yang optimal, layak dan terjamin kerja yang efektif.

Menurut T. Hani Handoko (2009:4) "Manajemen Sumber Daya Manusia adalah : Penarikan, seleksi, pengembangan, pemeliharaan dan penggunaan sumber daya rnanusia untuk mencapai suatu tujuan baik tujuan-tujuan individu maupun tujuan organisasi."

Menurut Alex S. Nitisemito (2010:13) Manajemen Sumber Daya Manusia adalah : "Suatu ilmu dan seni untuk melaksanakan antara lain perencanaan, pengorganisasian dan pengawasan, sehingga efektifitas dan efisiensi personalia dapat ditingkatkan semaksimal mungkin dalam pencapaian tujuan." 


\section{Pengertian Insentif}

Insentif merupakan salah satu perangsang dan pemberi semangat atau motivasi kepada seseorang dalam Lembaga atau Organisasi agar bekerja lebih giat didalam menyelesaikan beban kerjanya. Karena dengan adanya perangsang kerja seseorang dapat bekerja lebih baik sekalipun hal ini diluar gaji yang diterima setiap bulannya.

Sebagai sarana motivasi yang mendorong para Pegawai untuk bekerja dengan kemampuan yang optimal, yang dimaksudkan sebagai pendapatan ekstra diluar gaji atau upah yang telah ditentukan. Pemberian insintif yang dimaksudkan agar dapat memenuhi kebutuhan para Pegawai dan Keluarga mereka. Istilah sistem insentif pada umumnya digunakan untuk menggambarkan rencana-rencana pembayaran upah yang dikaitkan secara langsung atau tidak langsung dengan berbagai standard pekerja pegawai atau profitabilitas organisasi.

Insentif dapat dirumuskan sebagai balas jasa yang memadai kepada pegawai yang prestasinya melebihi setandar yang telah di tetapkan. Insentif merupakan suatu factor pendorong bagi pegawai untuk bekerja lebih baik agar kenerja pegawai dapat meningkat. Dari pengertian diatas untuk lebih jelas tentang insentif dibawah ini ada beberapa ahli manajemen mengemukakan pengertian insentif.

\section{Jenis-Jenis Insentif}

Jenis-jenis insentif dalam suatu perusahan harus dituangkan secara jelas sehingga dapat diketahui oleh pegawai dan oleh perusahaan tersebut dapat dijadikan kontribusi yang baik untuk dapat menambah gairah kerja bagi pegawai yang bersangkutan.
Menurut ahli manajemen Sumber Daya Manusia Siagian (2014: 268) jenisjenis insentif tersebut adalah :

1) Piece Work, Piece Work adalah teknik yang digunakan untuk mendorong kinerja pegawai berdasarkan hasil pekerjaan pegawai yang dinyatakan dalam jumlah unit produksi.

2) Bonus,Bonus adalah insintif yang diberikan kepada pegawai yang mampu bekerja sedemikian rupa sehingga tingkat produksi yang baku terlampaui.

3) Komisi,Komisi adalah bonus yang diterima karena berhasil melaksanakan tugas dan sering diterapkan oleh tenagatenaga penjualan.

4) Insentif bagi Eksekutif,Insentif bagi eksekutif adalah insentif yang diberikan kepada pegawai khususnya manajer atau pegawai yang memiliki kedudukan tinggi dalam suatu perusahaan, misalnya untuk membayar cicilan rumah, kendaraan bermotor, atau biaya pekerjaan umum dan penataan ruang anak.

5) Kurva Kematangan, Kurva kematangan adalah insentif yang diperikan kepada tenaga kerja yang karena masa kerja dan Golongan/Pangkat serta gaji tidak bisa mencapai pangkat dan penghasilan yang lebih tinggi lagi misalnya dalam bentuk penelitian ilmia atau dalam bentuk beban mengajar yang lebih besar dan sebagainya

\section{METODE PENELITIAN}

\section{Objek Penelitian}

Penelitian ini dilakukan di Kantor Satuan Polisi Pamong Praja Kabupaten Pesawaran beralamatkan Jalan Raya Kedondong Binong Desa Waylayap Komplek Perkantoran Pemerintah Daerah Kabupaten Pesawaran. Objek dari 
penelitian ini adalah Anggota Satuan Polisi Pamong Praja Kabupaten Pesawaran yang menerima insentif dimana penelitian ini berlangsung dari bulan Maret sampai dengan bulan Juli 2019.

\section{Metode dan Teknik Pengumpulan Data}

Dalam penelitian ini jenis data yang diperlakukan adalah :

\section{a. Data Primer}

Data primer ini nantinya merupakan data dasar yang akan diperoleh langsung tanpa perantara orang atau lembaga lain sebagai pihak ketiga. Data primer ini diperoleh dengan wawancara melalui responden dengan menggunakan daftar pertanyaan.

b. Data Sekunder

Data sekunder merupakan data yang diperoleh melalui orang lain yang berhubungan dengan permasalahan yang dipecahkan. Data sekunder ini diperoleh melalui cara studi documenter yaitu mengumpulkan dan mempelajari brosur-brosur serta dokumen organisasi.

\section{Sampel dan Populasi}

Langkah teknik pengumpulan data dalam penelitian ini adalah untuk pengambilan responden baik secara keseluruhan atau populasi nantinya. Menurut Nanang Martono (2011:124) mendefinisikan populasi adalah seluruh objek atau subjek yang berada pada suatu wilayah dan memenuhi syarat-syarat tertentu berkaitan dengan masalah penelitian, atau keseluruhan unit atau individu dalam ruang lingkup yang akan diteliti. Adapun Populasi dalam penelitian ini adalah Seluruh Anggota Satuan Polisi Pamong Praja Kabupaten Pesawaran yang menerima insentif dijadikan responden. Berdasarkan data yang ada jumlah Anggota Satuan Polisi Pamong Praja Kabupaten
Pesawaran yang menerima insentif adalah 400 orang.

Kemudian menurut S. Arikunto (2016:112) Apabila dalam suatu penelitian terhadap subjek yang kurang dari 100, maka di ambil semuanya sedangkan apabila subjek lebih dari 100 maka sampel yang diambil $10 \%, 15 \%$ atau lebih, dari seluruh populasi yang ada. Menurut data yang ada jumlah populasi dalam penelitian ini berjumlah 400 orang. Maka penulis melakukan pengambilan sampel sebagai responden sebesar $10 \%$ dari 400 orang yaitu 40 orang responden dan dengan menggunakan teknik cluster random sampling.

\section{Metode Analisis Data}

Analisis kualitatif dilakukan dengan analisis tabel tunggal atau secara parsial yang akan menggambarkan kriteria masing-masing variabel yaitu kriteria variabel Insentif dan Disiplin Kerja.

Analisa ini merupakan langkah untuk menentukan uji validasi atas butir soal variabel Insentif dan Disiplin Kerja dari hasil kuesioner kepada responden yang selanjutnya melakukan tabulasi data terhadap kedua variabel yang disimulasikan dalam pernyataan atau pertanyaan.

Sedangkan untuk mengetahui tingkat realibilitas kuesioner maka digunakan rumus Alpha Cronbach terhadap variabel Insentif dan Disiplin Kerja dari hasil penyebaran kuesioner kepada responden yang selanjutnya melakukan tabulasi data terhadap kedua variabel yang disimulasikan dalam pernyataan atau pertanyaan dengan perumusan

$$
r 11=\left\{\frac{N}{N-1}\right\}\left\{\frac{1-\sum \delta 1^{2}}{\delta t^{2}}\right\}
$$

(Sugiyono,2011;282) 
Keterangan :

$\mathrm{r} 11$ : Reabilitas instrumen.

$\mathrm{N}$ : Banyaknya butir soal.

$\sum \delta_{1}^{2}$ : Jumlah varian butir pertanyaan.

$\delta_{\mathrm{t}}{ }^{2}$ : Varians total. (Sugiyono,2011;282)

Pengujian Realibilitas instrumen dilakukan melalui program SPSS (Statistical Product and Service Solutions).

Analisis Kuantitatif, Untuk mengetahui Pengaruh Insentif dan Disiplin Kerja, maka analisis yang digunakan menggunakan rumus Regresi Tunggal (regresi sederhana)vrumusannya adalah :

$$
Y=a+b X
$$

Keterangan :

$\mathrm{Y}=$ Variabel Disiplin Kerja.

$\mathrm{a}=$ Variabel Tetap.

$\mathrm{b}=$ Koefisien (Peubah).

$\mathrm{X}=$ Variabel Insentif. (Algifari, 2012:48)

Kemudian langkah selanjutnya terhadap seluruh jawaban dari masingmasing responden dilanjutkan dengan penggolongan atau pengklasifikasian dalam setiap kategori. Penentuan kategori ini berdasarkan interval yang diperoleh dari "selisih antara skor tertinggi dan skor terendah dibagi lima" (Sujana, 2011:45).

Sehingga untuk menyatakan besar kecilnya sumbangan variabel $\mathrm{X}$ terhadap $\mathrm{Y}$ ditentukan dengan rumusan koefisien penentu atau koefisien determinasi sebagai berikut :

$$
K D=r 2 \times 100 \%
$$

Keterangan :

$\mathrm{KD}=$ Nilai Koefisien Determinasi.

$\mathrm{r}^{2}=$ Nilai Koefisien Korelasi. ( Algifari, $2012: 50)$

Sebagai pengujian lanjutannya yakni untuk uji signifikasi yang berfungsi untuk mencari makna pengaruh (keberartian) masing-masing antara variabel $\mathrm{X}$ terhadap variabel $Y$ sebagai pembuktian uji hipotesis, maka dari hasil Korelasi Pearson Product Moment tersebut di uji dengan uji hipotesis untuk mencari uji t dengan rumus

$$
\text { thitung }=\frac{r \sqrt{n-k}}{\sqrt{1-r 2}}
$$

Keterangan :

$\mathrm{t}_{\text {hitung }}=$ nilai uji $\mathrm{t}$.

$\mathrm{r} \quad=$ Nilai Koefisien Korelasi.

$\mathrm{n}=$ Jumlah Responden.

$\mathrm{k} \quad=$ Variabel Insentif.

Pengujian ini menggunakan program SPSS (Statistical Product and Service Solutions). Kriteria untuk uji t adalah sebagai berikut :

a. Apabila $\mathrm{t}$ hitung $>\mathrm{t}$ tabel pada taraf signifikan tertentu, maka berarti $\mathrm{H}_{0}$ diterima dan $\mathrm{H}_{\mathrm{a}}$ ditolak

b. Apabila $\mathrm{t}$ hitung $\leq \mathrm{t}$ tabel pada taraf signifikan tertentu, maka berarti $\mathrm{H}_{0}$ ditolak dan $\mathrm{H}_{\mathrm{a}}$ diterima.

Taraf signifikan dalam penelitian ini digunakan $\alpha=0.05$ atau $5 \%$. Yang dimaksud dengan Hipotesis nol $\left(\mathrm{H}_{0}\right)$ dan Hipotesis alternative $\left(\mathrm{H}_{\mathrm{a}}\right)$ adalah :

1) $\mathrm{H}_{\mathrm{a}}=\mathrm{r} \leq 0$ Berarti tidak ada Pengaruh Pemberian Insentif Terhadap Disiplin Kerja Anggota Satuan Polisi Pamong Praja Kabupaten Pesawaran.

2) $\mathrm{H}_{0}=\mathrm{r}>0$ Berarti ada Pengaruh Pemberian Insentif Terhadap Disiplin Kerja Anggota Satuan Polisi Pamong Praja Kabupaten Pesawaran

\section{HASIL DAN PEMBAHASAN}

\section{Uji Validitas dan Uji Rehabilitas}

Untuk mengetahui tingkat validitas tersebut, maka akan dilakukan terlebih 
dahulu perhitungan statistikdengan menggunakan SPSS ver.20. Adapun hasil output perhitungan uji validitas dapat dilihat pada tabel berikut :

Hasil Uji Validitas Variabel X (Insentif)

\begin{tabular}{|l|l|l|l|}
\hline $\begin{array}{l}\text { Item } \\
\text { Pertanyaan }\end{array}$ & rhitung & rtabel & Kesimpulan \\
\hline Item 1 & 0,773 & 0,2638 & Valid \\
Item 2 & 0,562 & 0,2638 & Valid \\
Item 3 & 0,650 & 0,2638 & Valid \\
Item 4 & 0,781 & 0,2638 & Valid \\
Item 5 & 0,581 & 0,2638 & Valid \\
Item 6 & 0,681 & 0,2638 & Valid \\
Item 7 & 0,773 & 0,2638 & Valid \\
Item 8 & 0,823 & 0,2638 & Valid \\
Item 9 & 0,781 & 0,2638 & Valid \\
Item 10 & 0,710 & 0,2638 & Valid \\
\hline
\end{tabular}

Sumber: Data primer diolah, 2019

Hasil Uji Validitas Variabel Y (Disiplin kerja)

\begin{tabular}{|l|l|l|l|}
\hline $\begin{array}{l}\text { Item } \\
\text { Pertanyaan }\end{array}$ & rhitung & rtabel & Kesimpulan \\
\hline Item 1 & 0,629 & 0,2638 & Valid \\
Item 2 & 0,662 & 0,2638 & Valid \\
Item 3 & 0,662 & 0,2638 & Valid \\
Item 4 & 0,514 & 0,2638 & Valid \\
Item 5 & 0,533 & 0,2638 & Valid \\
Item 6 & 0,601 & 0,2638 & Valid \\
Item 7 & 0,432 & 0,2638 & Valid \\
Item 8 & 0,514 & 0,2638 & Valid \\
Item 9 & 0,377 & 0,2638 & Valid \\
Item 10 & 0,662 & 0,2638 & Valid \\
\hline
\end{tabular}

Sumber: Data primer diolah, 2019

Berdasarkan pada tabel diatas, terlihat bahwa hasil perhitungan yang menyangkut hubungan atau korelasi antara masing-masing indikator yang digunakan dalam penelitian yakni Insentif dan Disiplin Kerja terhadap total skor konstruk dari setiap variabel dengan alat bantu perhitungan SPSS vers.20 menunjukkan hasil yang signifikan dan menunjukkan bahwa rhitung lebih besar dari rtabel .Sehingga disimpulkan bahwa semua item pertanyaan dinyatakan valid.

Uji reliabilitas digunakan untuk mengukur suatu kuesioner yang merupakan indikator dari variabel. Untuk mengukur reliabilitas dengan menggunakan statistik Cronbach Alpha. Suatu variabel dikatakan reliabel jika memiliki Cronbach Alpha lebih dari 0,60. Untuk menghitung Cronbach Alpha dapat menggunakan rumus :

$$
r 11=\left\{\frac{N}{N-1}\right\}\left\{\frac{1-\sum \delta 1^{2}}{\delta t^{2}}\right\}
$$

(Sugiyono,2011;282)

Keterangan :

r 11 : Reabilitas instrumen.

$\mathrm{N} \quad$ : Banyaknya butir soal.

$\sum \delta 1^{2}$ : Jumlah varian butir pertanyaan.

$\delta \mathrm{t}^{2} \quad$ : Varians total.

(Sugiyono,2011;282)

Hasil pengujian reliabilitas instrumen menggunakan alat bantu statistik SPSS vers.20 . Adapun hasil output dapat diketahui sebagaimana dalam tabel berikut : Hasil Uji Reliabilitas

\begin{tabular}{|l|l|l|}
\hline Variabel & $\begin{array}{l}\text { Cronbach } \\
\text { Alpha }\end{array}$ & Keterangan \\
\hline $\mathrm{X}$ & 0,892 & Reliabel \\
$\mathrm{Y}$ & 0,757 & Baik \\
& & Reliabel \\
& & Diterima \\
\hline
\end{tabular}

Sumber: Data primer diolah, 2019

Dari tabel dapat diketahui bahwa masing-masing variabel memiliki Cronbach Alpha lebih dari 0,60 sehingga dapat disimpulkan bahwa semua variabel $X$ (Insentif) dan Y (Disiplin Kerja) adalah reliabel.

\section{Uji Analisis Regresi Sederhana}

Dengan menggunakan analisis regresi linear maka akan mengukur perubahan variabel terikat berdasarkan perubahan variabel bebas. Secara umum, rumus persamaan regresi linear sederhana adalah :

$$
Y=a+b X
$$

Keterangan :

$\mathrm{Y}=$ Variabel Disiplin Kerja. 
$\mathrm{a}=$ Variabel Tetap.

$\mathrm{b}=$ Koefisien (Peubah).

$\mathrm{X}=$ Variabel Insentif.

Sementara untuk mengetahui nilai koefisien regresi tersebut, dapat dilihat dari hasil output menggunakan alat bantu SPSS vers. 20 pada tabel koefisien dibawah ini: Hasil Perhitungan Regresi Linier Sederhana X.Y Coefficientsa

\begin{tabular}{|c|c|c|c|c|c|}
\hline \multirow[t]{2}{*}{ Model } & \multicolumn{2}{|c|}{$\begin{array}{l}\text { Unstandardized } \\
\text { Coefficients }\end{array}$} & \multirow{2}{*}{\begin{tabular}{|l|} 
Standardize \\
$\mathrm{d}$ \\
Coefficients \\
Beta
\end{tabular}} & \multirow[t]{2}{*}{$T$} & \multirow[t]{2}{*}{ Sig. } \\
\hline & B & Std. Error & & & \\
\hline $\begin{array}{l}\text { (Constant) } \\
\text { Insentif }\end{array}$ & $\begin{array}{l}21,213 \\
.521\end{array}$ & $\begin{array}{l}3,883 \\
093\end{array}$ & .673 & $\begin{array}{l}5,463 \\
5,607\end{array}$ & \begin{tabular}{|l}
.000 \\
.000
\end{tabular} \\
\hline
\end{tabular}

a. Dependent Variable: disiplin kerja

Sumber : Data primer diolah, 2019

Dari tabel diatas, dapat diketahui bahwa $\mathrm{a}=$ angka konstan dari unstandardized coefficients dalam kasus ini nilainya sebesar 21,2113. Angka ini merupakan angka konstan yang mempunyai arti bahwa jika tidak ada Insentif (X) maka nilai konsisten Disiplin Kerja (Y) adalah sebesar 21,2113. $b=$ angka koefisien regresi nilainya sebesar 0,521. Angka ini mengandung arti bahwa setiap penambahan $1 \%$ tingkat variabel Insentif $(\mathrm{X})$ maka nilai variabel Disiplin Kerja (Y) pada Satuan Polisi Pamong Praja Kabupaten Pesawaran akan meningkat sebesar 52,1\%.

Karena nilai koeefisien regresi bernilai positif, maka dengan demikian dapat disimpulkan bahwa Insentif (X) berpengaruh positif terhadap Disiplin Kerja (Y). Sehingga didapat persamaan regresi Y $=21,2113+0,521 \mathrm{X}$.

Uji Hipotesis Ada Pengaruh yang signifikan antara Insentif dan Disiplin Kerja membandingkan nilai Sig dengan $\alpha$.

Perhitungan pengaruh antara variabel Insentif (X) terhadap variabel Disiplin Kerja (Y) pada Satuan Polisi Pamong Praja Kabupaten Pesawaran menggunakan hasil perhitungan alat bantu SPSS vers.20 dengan output SPSS adalah:
1) Jika nilai signifikansi (sig) lebih kecil dari probabilitas 0,05 berarti bahwa ada pengaruh Insentif $(\mathrm{X})$ terhadap Disiplin $\operatorname{Kerja~(Y).~}$

2) Jika nilai signifikansi (sig) lebih besar dari probabilitas 0,05 berarti bahwa tidak ada pengaruh Insentif (X) terhadap Disiplin Kerja (Y).

Berdasarkan output pada Tabel diketahui bahwa nilai signifikansi (sig.) sebesar 0,000 lebih kecil dari probabilitas 0,05 . Sehingga dapat disimpulkan bahwa H0 ditolak dan Ha diterima yang berarti bahwa "Ada pengaruh Pemberian Insentif (X) terhadap Disiplin Kerja (Y)".

Uji Hipotesis Ada Pengaruh yang signifikan antara Insentif dan Disiplin Kerja membandingkan nilai $\mathrm{t}$ hitung dengan $\mathrm{t}$ tabel .

Sebagai pengujian lanjutannya yakni untuk uji signifikasi yang berfungsi untuk mencari makna pengaruh (keberartian) masing-masing antara variabel $\mathrm{X}$ terhadap variabel $\mathrm{Y}$ sebagai pembuktian uji hipotesis, maka dari hasil Korelasi Pearson Product Moment tersebut di uji dengan uji hipotesis untuk mencari uji $\mathrm{t}$ dengan rumus :

$$
t \text { hitung }=\frac{r \sqrt{n-k}}{\sqrt{1-r 2}}
$$

Keterangan :

t hitung = nilai uji t.

$\mathrm{r} \quad=$ Nilai Koefisien Korelasi.

$\mathrm{n} \quad=$ Jumlah Responden.

$\mathrm{k} \quad=$ Variabel Insentif.

Dimana dasar dari pengambilan keputusan dalam uji t adalah :

1) Jika nilai thitung lebih besar dari t tabel berarti bahwa ada pengaruh Insentif (X) terhadap Disiplin Kerja (Y).

2) Sebaliknya, jika nilai t hitung lebih kecil dari $t$ tabel berarti bahwa tidak ada pengaruh Insentif $(\mathrm{X})$ terhadap Disiplin Kerja (Y). 
Berdasarkan output SPSS vers.20 yang ada pada tabel, diketahui nilai t hitung sebesar 5,607. Karena nilai t hitung sudah ditemukan linggal melihat nilai dari t tabel . Adapun rumus dalam mencari t tabel adalah

$$
\begin{gathered}
\text { Nilai } \alpha / 2=0,05 / 2=0,025 \\
d f(\text { degree of freedom })=(N-2)=(40-2)=38
\end{gathered}
$$

Nilai t tabel $(0,025 ; 38)$, maka nilai $\mathrm{t}$ tabel $=2,02439$.

Karena nilai t hitung sebesar 5,607 lebih besar dari t tabel sebesar 2,02439, dapat disimpulkan bahwa H0 ditolak dan Ha diterima yang berarti bahwa "Ada Pengaruh Pemberian Insentif (X) terhadap Disiplin Kerja (Y)”.

\section{KESIMPULAN DAN SARAN}

\section{Kesimpulan}

Dari pembahasan yang telah diuraikan, Penelitian mengenai Pengaruh Pemberian Insentif Terhadap Disiplin Kerja Anggota pada Satuan Polisi Pamong Praja Kabupaten Pesawaran menghasilkan kesimpulan yang didasarkan pada analisis bahwa Pemberian Insentif memberikan pengaruh terhadap Disiplin Kerja Anggota pada Satuan Polisi Pamong Praja Kabupaten Pesawaran. Hasil analisis menunjukkan bahwa Pemberian Insentif berpengaruh secara positif dan signifikan sebesar 45,3\% terhadap Disiplin Kerja Anggota pada Satuan Polisi Pamong Praja Kabupaten Pesawaran. Sedangkan 44,7\% disiplin kerja dipengaruhi oleh variabel yang lain yang tidak diteliti. Faktor lain yang tidak dijelaskan dalam penelitian ini menurut penulis dapat dipengaruhi oleh kinerja, motivasi kerja, lingkungan kerja dan lainnya.

\section{Saran}

1. Bagi Satuan Polisi Pamong Praja Kabupaten Pesawaran, Insentif terbukti memberikan pengaruh yang signifikan terhadap disiplin kerja anggotanya. Oleh karena itu, hendaknnya untuk dapat mempertimbangkan kembali untuk mengusulkan kepada Bupati Pesawaran agar kembali memberikan Insentif kepada anggotanya.

2. Bagi anggota Satuan Polisi Pamong Praja Kabupaten Pesawaran, hendaknya memiliki kesadaran untuk selalu dan harus memperhatikan aspek disiplin, terutama aspek kesadaran dan kesediaan mentaati semua peraturan organisasi dan norma-norma sosial yang berlaku. Salah satunya yaitu selalu datang dan pulang tepat pada waktunya dan mengerjakan semua pekerjaannya dengan baik.

3. Bagi peneliti selanjutnya, hendaknya dapat menganalisis faktor-faktor lainnya yang berpengaruh terhadap peningkatan disiplin kerja anggota Satuan Polisi Pamong Praja Kabupaten Pesawaran agar penelitian ini dapat lebih baik lagi.

\section{DAFTAR PUSTAKA}

Arikunto, Suharsimi. 2016. Prosedur Penelitian Suatu Pendekatan Praktik. Jakarta:Bumi Aksara,

Bacal, Robert. 2015. Performance Management (alih bahasa oleh Surya Dharma). Jakarta:PT.Sun.

Guntur, Letje. 2000. Jaminan Sosial Tenaga Kerja. Jakarta:Erlangga.

Heidjrachman dan Suad Husnan. 2007. Manajemen Sumber Daya Manusia. Bandung:Remaja Rosda Karya.

Handoko, T.Hani dan Reksohadiprojo.2009. Manajemen 
Sumber Daya Manusia dan

Perusahaan (edisi keempat).

Yogyakarta:BPFE UGM.

Hasibuan, Malayu S.P. 2011. Manajemen Sumber Daya Manusia (edisi revisi). Jakarta:Bumi Aksara.

Martono, Nanang. 2011. Metode Analisis Data. Jakarta:Rineka Cipta.

Rivai, Veithzal. 2014. Manajemen Sumber Daya Manusia untuk Perusahaan (edisi kedua). Jakarta:Raja Grafindo Persada

Siagian, Sondang P. 2014. Teori dan Praktek Kepemimpinan. Jakarta:Rineka Cipta.

Sinambela, Lijan Poltak, dkk. 2012. Kinerja Pegawai Teori Pengukuran dan Implikasi. Yogyakarta:Graha Ilmu.

Sastrohadiwiryo, B.Siswanto. 2005. Manajemen Tenaga Kerja (edisi ketiga). Jakarta:Bumi Aksara.

Simamora, Hendry. 2012. Manajemen Sumber Daya Manusia (edisi satu). Yogyakarta:STIE YKPN Yogyakarta

Sirait, Justin T. 2006. Memahami AspekAspek Pengelolaan Sumber Daya Manusia dalam Organisasi. Jakarta:Grasindo.

Sudjana. 2011. Metode Statistika. Bandung:Tarsito.

Sugiono. 2011. Statistika Untuk Penelitian. Bandung:Alfabeta. 